\title{
Effect of analcite on cadmium phytoavailability and phytotoxity
}

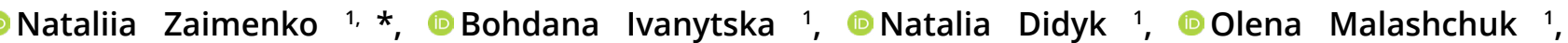

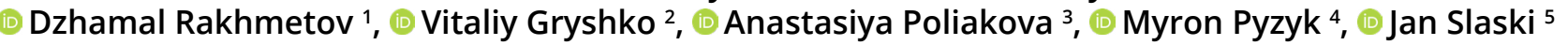

\author{
1 M.M. Gryshko National Botanical Garden, National Academy of Sciences of Ukraine, Tymiryazevska str. 1, 01014 Kyiv, Ukraine; \\ *zaimenkonv@ukr.net \\ ${ }^{2}$ Kryvyi Rig Botanical Garden, National Academy of Sciences of Ukraine, Marshaka str. 50, 50089 Kryvyi Rig, Ukraine \\ ${ }_{3}^{3}$ Oleksandr Dovzhenko Hlukhiv National Pedagogical University, Kyivo-Moskovska str. 24, 41400 Hlukhiv, Ukraine \\ ${ }^{4}$ United Institute of Modern Technologies (UloMT), 10225 str., 147, Edmonton, Alberta, T5N 3C1, Canada \\ ${ }^{5}$ Bio-Industrial Services Division, InnoTech Alberta, Hwy 16A str., 75, Vegreville, Alberta, T9C 1T4, Canada
}

\begin{abstract}
The interactive effects of $\mathrm{Cd}$ and natural siliceous mineral analcite on Cd phytotoxicity and rate of accumulation in plant tissues have been analyzed. The test-plants of corn and hemp were grown in pots under controlled conditions of light, temperature, and soil moisture for 21 days in experiments modeling the following treatments: (1) without any amendments (control); (2) with the application of $0.1 \%$ and $0.5 \%$ (by weight) of $\mathrm{CdSO}_{4^{\prime}}(3) \mathrm{Cd}$ salts $\left(\mathrm{CdSO}_{4}\right)+$ analcite $0.1 \mathrm{~g}, 0.25 \mathrm{~g}$, and $0.5 \mathrm{~g}$ per container. Test-plants performance was assessed by their growth characteristics (shoot height and root length), the content of photosynthetic pigments, macro- and micronutrients in leaves. The effect of $\mathrm{Cd}$ on maize and hemp plants inhibited their growth, chlorophyll biosynthesis in the leaves, led to a change in the balance of macro- and microelements, which leads to the accumulation of $\mathrm{Cd}$ in the tissues of shoots of both studied crops. Application of analcite partially compensated for the negative effects of Cd salts on the crop's growth, chlorophyll content, and balance of nutrients and reduced $\mathrm{Cd}$ accumulation significantly in shoots.
\end{abstract}

Keywords: analcite, Cd, phytoavailability, phytotoxicity, macronutrients accumulation, micronutrients accumulation, photosynthetic pigments, corn, hemp

Authors' contributions: Nataliia Zaimenko conceived of the presented idea, developed the theory and performed the computations. Bohdana Ivanytska and Natalia Didyk carried out the experiment wrote the manuscript with support from Vitaliy Gryshko, Myron Pyzyk, Jan Slaski. Olena Malashchuk performed measurements of the macro- and microelements in the plant material and soil samples using inductively coupled plasma spectrometer. Dzhamal Rakhmetov and Anastasiya Poliakova provided seed material of hemp. All authors discussed the results and contributed to the final manuscript.

Funding: This study was conducted in the frames of institutional research thematics. No other financial sources were declared. Competing Interests: The authors declared no conflict of interest.

\section{Introduction}

The rising concern about cadmium (Cd) contamination of agricultural soils is not only due to its phytotoxicity to crops, but also for its potential human and animal health hazards associated with food chain contamination (Augustsson et al., 2015; Li et al., 2018). Cd pollution of agricultural production is an acute problem for Ukraine due to the growing chemicalization of agriculture (Chorna et al., 
2018). During the last decades, the amount of pesticides and fertilizers used in agriculture has been growing steadily, leading to increased chemical and biological pollution of soils and water sources (Zhigailo, 2011). Other important sources of $\mathrm{Cd}$ pollution are emissions from industry and thermal power plants. In humans and other animals, cadmium may cause carcinogenic, embryotoxic, and teratogenic effects (Augustsson et al., 2015; Krychkovska et al., 2017). Most of Cd received by a human comes from plant foods. Cd is extremely easily transferred from the soil to plants; the latter absorb up to $70 \%$ of cadmium from the soil and only $30 \%$ - from the air. In Ukraine, in 2007, when testing the $\mathrm{Cd}$ content in the laboratory of the products of six well-known sunflower seed producers, in all samples $\mathrm{Cd}$ exceeded the maximum permissible concentration $(0.1 \mathrm{mg} /$ $\mathrm{kg}$ ). The highest cadmium content was $0.4 \mathrm{mg} /$ $\mathrm{kg}$ (four times higher than normal), the lowest - $0.148 \mathrm{mg} / \mathrm{kg}$ (Krychkovska et al., 2017).

For plants, $\mathrm{Cd}$ is a micronutrient, easily assimilated due to the flexible specificity of ion channels and divalent metal transporters (Loi et al., 2018). Upon accumulation, Cd directly affects some metabolic processes in various cellular organelles, especially chloroplasts. In toxic concentrations $\mathrm{Cd}$ disrupts normal metabolism leading to diverse morphological, physiological, biochemical and cellular changes (Simova-Stoilova et al., 2004). The excess of $\mathrm{Cd}$ accumulated in plants could cause $\mathrm{Fe}, \mathrm{Mg}, \mathrm{Ca}$ deficiency and reduce chlorophyll content. Besides, it also inhibits plant growth and respiration, destroys the ultrastructure of plant cells (nucleus, chloroplast, and mitochondria) even could lead to the death of plants (Hussain et al., 2013; Dubey et al., 2014).

The mobility of heavy metals in the soils is determined by the particle size, reaction of the soil solution, soil physical characteristics, moisture level, and other edaphic and meteorological factors (Feszterová et al., 2021). The leading process in the binding of cadmium salts in the soil is its adsorption by clay minerals as well as the interaction of ions with hydroxyl groups of different compounds present in the soil solution, iron oxides, and organic matter (Khan et al., 2017).

It is important to note the fact of the high mobility of cadmium ions in the soils due to its good ability to transfer from the solid phase to liquid and vice versa, which complicates the prediction of its up-take rate by plants. To reduce the mobility and toxicity of $\mathrm{Cd}$, various amendments, including industrial wastes (red mud, steel slags), iron oxides or hydroxides, clay minerals (zeolites, sepiolite, apatite), nano-materials (nano-hydroxyapatite particles, stabilized iron sulfate nanoparticles), activated carbon and composted biosolids were proposed (Li et al., 2018). Their mode of action is based on accelerating the processes of complexation, adsorption or redox reactions, and promoting surface precipitation reactions, metal binding, and fixation inside mineral particles. In recent years, many efforts have been made to evaluate the potential of these amendments to immobilize Cd in soils as well as their effects on soil ecosystem. Apart from their effect on $\mathrm{Cd}$ availability to crops, these amendments increase soil fertility due to their ability to increase soil cation exchange capacity, intensify microbiological activity, and improve the physical structure of soils.

Natural siliceous minerals present promise as environmentally friendly meliorantsstabilizers of heavy metal ions in the soil (Silva et al., 2017). Natural siliceous minerals do not impose any harm to soil microbiota and were shown to have beneficial effect on soil physical and agrochemical characteristics and crop productivity (Zaimenko et al., 2018, 2021). They are stable in the soil environment and, after having been applied once, express their effect for many years.

The physiological mechanisms of the protective effect of $\mathrm{Si}$ against metal toxicity include reduction of metal solubility via $\mathrm{Si}-$ increased ionic strength or $\mathrm{pH}, \mathrm{Si}$-mediated release of phenolics and metal, and $\mathrm{Si} \mathrm{co}^{-}$ precipitation either in different parts of the plant or in the growth media. Besides, Si has also been shown to inhibit root-to-shoot transport of toxic metals, increase binding of metals to cell walls decreasing concentrations of metals in the symplast, and reduce membrane lipid peroxidation via stimulating enzymatic and nonenzymatic antioxidants (Liang et al., 2007).

It was shown to have a marked positive effect of analcite on the functional state of living organisms. The inclusion of analcite in fertilizer promotes root development, improves agrophysical soil characteristics by increasing moisture level and creating chemical depot for macro- and micronutrients. 
It is readily available in Ukraine (Vinnytsia and Rivne regions) and presents an inexpensive and environmentally safe source of fertilizers for agricultural needs.

Corn and hemp are valuable crops and suitable models to study the physiological changes responsible for adaptation to stressful environmental conditions. Corn, as one of the most popular cereal grain, is widely cultivated across the world. It is an economically important crop for Ukraine. Therefore, it is urgent to elucidate physiological mechanisms underlying the accumulation of $\mathrm{Cd}$ in corn shoots. The literature reports significant genotypic differences in $\mathrm{Cd}$ concentration among corn cultivars and varieties as well as the substantial effect of environmental factors and agricultural practices on this process (Hussain et al., 2013).

Hemp is known for its tolerance to elevated heavy metals content in soils and for the ability to accumulate relatively high levels of these toxic elements, often without any or with negligible adverse effects on growth and yield (Linger et al., 2005). The superior attributes of hemp as a heavy metal hyperaccumulator, which are utilized for phytoremediation (extraction of soil pollutants by the plants) (Adiloglu, 2018), are highly undesirable from the crop production perspective because the metals are often deposited in edible parts of the plant, for instance, in the grain. Since these elements can be retained for several years in human and animal organisms, consumption of foods containing high levels of heavy metals may induce chronic toxicity.

The objective of our study was to assess alleviating effect of natural siliceous mineral analcite on $\mathrm{Cd}$ phytotoxicity and accumulation rate in corn and hemp, depending on this toxic metal concentration in the soil in model laboratory experiments.

\section{Material and methods}

\section{Sources of $\mathrm{Cd}$ and siliceous mineral}

$\mathrm{Cd}$ salt used in the tests was $\mathrm{CdSO}_{4}$ applied as $0.1 \%$ and $0.5 \%$ solutions in distilled water to soil substrate (gray podzol) once at the beginning of the experiments. Natural siliceous mineral (analcite) was applied simultaneously with a Cd salt solution at a rate of 100,250 , and $500 \mathrm{mg}$ per pot with a volume of 0.51 . The control was without $\mathrm{Cd}$ and siliceous mineral.

Test-plants, experimental setup, and cultivation conditions

The seeds of corn (Zea mays L. 'Orbit') were obtained from the Institute of Plant Physiology and Genetics of the National Academy of Sciences of Ukraine (Kyiv, Ukraine). The seeds of hemp (Cannabis sativa L. 'Hliana') were obtained from the Oleksandr Dovzhenko Hlukhiv National Pedagogical University. The experiments were conducted at the Department of Allelopathy, M.M. Gryshko National Botanical Garden of the National Academy of Sciences of Ukraine (Kyiv, Ukraine).

Test-plants were grown in the plant growing chambers, in 0.51 plastic pots filled with $0.7 \mathrm{~kg}$ of gray podzol soil sterilized in an oven at $100^{\circ} \mathrm{C}$ for two hours, air-dried, and sieved through $2 \mathrm{~mm}$ sieve. The test-plants were grown with a density of six plants per pot for 21 days under controlled conditions: air temperature of $20-22^{\circ} \mathrm{C}$, illumination of 2500 lux, and soil moisture of $50-60 \%$ of the field capacity. The experiments were replicated six times.

\section{Measurements}

The macro- and microelements in soil samples were determined using inductively coupled plasma spectrometer iCAP 6300 DUO from Thermo Fisher Scientific, USA (2006). Their extraction was conducted with 1N HCl (Rinkis \& Nollendorff, 1982). The photosynthetic pigments (chlorophylls a and $b$, and carotenoids) were extracted from freshly collected leaves of the test-plants with dimethylsulfoxide (DMSO) (Wellburn, 1994). Their content was determined spectrophotometrically with SPECORD 200 (Analytik, Jena). The test plants dry weight was determined at the end of the experiments.

\section{Statistical analysis}

The statistical operations were conducted using Statistica 10.0 software (Stat Soft. Inc., Tulsa, USA, 2011).

\section{Results}

Application of $\mathrm{CdSO}_{4}$ led to the accumulation of this toxic metal in the foliar tissues of corn and hemp test-plants (Tables 1 \& 2). 
Table 1. Content of macro- and micronutrients ( $g$ per kg of dry weight) in the foliar tissues of corn exposed to $\mathrm{CdSO}_{4}$ applied alone and mixed with analcite. LSD - the list significant difference $(n=6)$.

\begin{tabular}{lllllllllll}
\hline \multirow{2}{*}{ Nutrients } & \multirow{2}{*}{ Control } & $\mathrm{CdSO}_{4}$ & \multicolumn{9}{c}{$0.1 \% \mathrm{CdSO}_{4}+$ analcite } & \multicolumn{2}{c}{$0.5 \% \mathrm{CdSO}_{4}+$ analcite } & LSD \\
\cline { 3 - 9 } & $0.1 \%$ & $0.5 \%$ & $0.1 \mathrm{~g}$ & $0.25 \mathrm{~g}$ & $0.5 \mathrm{~g}$ & $0.1 \mathrm{~g}$ & $0.25 \mathrm{~g}$ & $0.5 \mathrm{~g}$ & $(\mathrm{P}<0.05)$ \\
\hline $\mathrm{K}$ & 65450 & 48500 & 34750 & 57410 & 97450 & 87760 & 71600 & 48550 & 89940 & 11.2 \\
$\mathrm{P}$ & 5624 & 5532 & 5272 & 5892 & 4927 & 5158 & 3939 & 5999 & 4648 & 8.8 \\
$\mathrm{Ca}$ & 8542 & 6894 & 6771 & 7362 & 9819 & 9978 & 8111 & 8967 & 10870 & 14.5 \\
$\mathrm{Mg}$ & 2758 & 2485 & 2691 & 2631 & 2792 & 3479 & 2550 & 3017 & 3050 & 9.7 \\
$\mathrm{~S}$ & 3965 & 8258 & 4149 & 5765 & 4084 & 3730 & 3909 & 3442 & 3074 & 8.6 \\
$\mathrm{Fe}$ & 387 & 1557 & 325 & 587 & 343 & 371 & 349 & 647 & 296 & 5.6 \\
$\mathrm{Si}$ & 1023 & 677 & 391 & 979 & 930 & 1012 & 674 & 1033 & 771 & 3.6 \\
$\mathrm{Al}$ & 189 & 1578 & 216 & 200 & 219 & 226 & 208 & 261 & 156 & 3.7 \\
$\mathrm{Mn}$ & 38 & 72 & 38 & 42 & 32 & 37 & 28 & 46 & 34 & 1.3 \\
$\mathrm{Zn}$ & 69.74 & 83.78 & 65.98 & 65.62 & 63.35 & 59.93 & 59.67 & 58.73 & 61.97 & 2.4 \\
$\mathrm{Cu}$ & 16.59 & 12.07 & 6.92 & 6.95 & 5.96 & 7.05 & 5.34 & 5.17 & 6.68 & 1.1 \\
$\mathrm{Cd}$ & 7.97 & 9.48 & 18.40 & 9.78 & 9.67 & 8.32 & 16.76 & 10.22 & 8.37 & 1.4 \\
\hline
\end{tabular}

Table 2. Content of macro- and micronutrients (g per kg of dry leaf weight) in the foliar tissues of hemp plants exposed to $\mathrm{CdSO}_{4}$ applied alone and mixed with analcite. LSD - the list significant difference $(n=6)$.

\begin{tabular}{lllllllllll}
\hline \multirow{2}{*}{ Nutrients } & Control & $\mathrm{CdSO}_{4}$ & \multicolumn{9}{c}{$0.1 \% \mathrm{CdSO}_{4}+$ analcite } & \multicolumn{2}{c}{$0.5 \% \mathrm{CdSO}_{4}+$ analcite } & LSD \\
\cline { 3 - 9 } & $0.1 \%$ & $0.5 \%$ & $0.1 \mathrm{~g}$ & $0.25 \mathrm{~g}$ & $0.5 \mathrm{~g}$ & $0.1 \mathrm{~g}$ & $0.25 \mathrm{~g}$ & $0.5 \mathrm{~g}$ & $(\mathrm{P}<0.05)$ \\
\hline $\mathrm{K}$ & 22880 & 38410 & 36420 & 29513 & 30170 & 29980 & 26380 & 26810 & 36820 & 4.5 \\
$\mathrm{P}$ & 14790 & 10370 & 13250 & 15380 & 14040 & 13230 & 8764 & 9913 & 12740 & 4.8 \\
$\mathrm{Ca}$ & 41523 & 44100 & 40710 & 26920 & 31050 & 28630 & 27580 & 23470 & 27590 & 9.1 \\
$\mathrm{Mg}$ & 8956 & 13030 & 14160 & 32660 & 7260 & 7401 & 5854 & 5681 & 7083 & 3.6 \\
$\mathrm{~S}$ & 39860 & 20850 & 26880 & 47800 & 47790 & 44260 & 49340 & 44170 & 51190 & 5.1 \\
$\mathrm{Fe}$ & 446 & 527 & 446 & 415 & 433 & 482 & 290 & 380 & 359 & 3.6 \\
$\mathrm{Si}$ & 1665 & 6530 & 1004 & 1045 & 2103 & 1831 & 1761 & 1705 & 2074 & 3.4 \\
$\mathrm{Al}$ & 228 & 230 & 162 & 275 & 268 & 254 & 133 & 187 & 157 & 2.8 \\
$\mathrm{Mn}$ & 98.76 & 123.80 & 140.20 & 74.43 & 84.36 & 90.88 & 69.99 & 75.32 & 86.88 & 2.4 \\
$\mathrm{Zn}$ & 59.87 & 80.67 & 77.09 & 84.61 & 98.40 & 61.09 & 55.08 & 49.64 & 57.76 & 1.2 \\
$\mathrm{Cu}$ & 21.12 & 28.05 & 22.64 & 23.36 & 24.87 & 21.21 & 17.14 & 13.15 & 16.57 & 0.6 \\
$\mathrm{Cd}$ & 49.58 & 44.18 & 125.90 & 65.73 & 68.89 & 35.09 & 121.05 & 89.13 & 58.87 & 0.9 \\
\hline
\end{tabular}

This effect positively correlated with the $\mathrm{Cd}$ salt concentration. Hemp accumulated 4.2- to 8.7-fold higher amounts of $\mathrm{Cd}$ in foliar tissues as compared to corn. The rate of accumulation positively depended on the rate of application of $\mathrm{CdSO}_{4}$. The comparative analysis of the content of other nutrients in the foliar tissues of hemp and corn revealed significant differences between these two species. Particularly, the application of $0.1 \%$ of $\mathrm{CdSO}_{4}$ to corn led to the increase of $\mathrm{Al}, \mathrm{Mn}, \mathrm{Fe}, \mathrm{S}$, and Zn contents in foliar tissues. Higher $(0.5 \%)$ concentration of the $\mathrm{Cd}$ salts inhibited up-take of all studied macro- and micronutrients (Table 1). 
In contrast to corn, the exposition of hemp plants to $0.1 \%$ of $\mathrm{CdSO}_{4}$ did not stimulate the accumulation of $\mathrm{Al}, \mathrm{S}$, and $\mathrm{Zn}$ in foliar tissues. However, it still stimulated absorption and allocation to leaves of $\mathrm{Ca}, \mathrm{Fe}, \mathrm{Mg}, \mathrm{K}, \mathrm{Mn}, \mathrm{Na}$, and $\mathrm{Cu}$ (Table 2).

Except for $\mathrm{Cd}, \mathrm{Mn}, \mathrm{Na}$, and $\mathrm{Mg}$, with the increase in the $\mathrm{Cd}$ salt concentration, the degree of the mentioned above stimulation decreased.

Combined application of $\mathrm{Cd}$ salt with analcite significantly modified absorption and accumulation of Cd by corn and hemp plants. The character of the analcite effect depended on its concentration and the species of a test-plant. When applied in combination with $\mathrm{CdSO}_{4}$ in low concentrations (100-250 mg), analcite slightly stimulated absorption and accumulation of $\mathrm{Cd}$ by the test-plants. While at the highest tested concentration $(500 \mathrm{mg}$ per container), analcite significantly reduced the amount of $\mathrm{Cd}$ accumulated in the leaves of both test plants (Tables 1 \& 2). Application of this siliceous mineral significantly stimulated uptake of $\mathrm{Al}, \mathrm{Ca}, \mathrm{K}, \mathrm{Na}, \mathrm{Mg}$, and $\mathrm{Si}$ in corn, and $\mathrm{Al}, \mathrm{P}, \mathrm{S}, \mathrm{Zn}$, and $\mathrm{Si}$ in hemp plants exposed to $0.1 \%$ or $0.5 \% \mathrm{CdSO}_{4}$. The capacity of corn treated with analcite to accumulate $\mathrm{Al}, \mathrm{Ca}$, $\mathrm{K}, \mathrm{Na}, \mathrm{Mg}$, and $\mathrm{Si}$ under Cd-stress was even higher than in control (without Cd). A similar tendencies were observed for $\mathrm{S}$ and $\mathrm{Zn}$ accumulation in hemp leaves. In addition, the application of this siliceous mineral decreased the content of toxic metals such as $\mathrm{Fe}, \mathrm{Cu}$, and Mn in both test-plants.

Under Cd stress, the decrease in chlorophyll $a$ and $b$ content and slightly stimulated carotenoids content in the leaves of the target plants were observed (Tables $3 \& 4$ ).

Hemp photosynthetic system showed higher sensitivity to Cd toxicity as compared to corn. This correlates well with the capacity of the tested species to accumulate this toxic metal. Application of analcite with the cadmium salt partially compensated the negative effect of $\mathrm{Cd}$ on photosynthetic pigments content in both test plants. The analcite effect positively correlated with the mineral concentration, reaching the highest values when the latter was applied at a rate of $500 \mathrm{mg}$ per pot.

Observed physiological changes in the content of the photosynthetic pigment as well as macro- and micronutrients balance in the leaves of corn and hemp were in good agreement with their growth characteristics (Table 5).

Exposition of both test-plants to $\mathrm{CdSO}_{4}$, especially applied at the highest concentration, significantly retarded their growth characteristics. Corn growth parameters showed more sensitivity to $\mathrm{Cd}$ toxicity as compared to hemp. Corn shoots were more affected than roots. Slight stimulation of the corn root system was observed when Cd salt was applied at the lowest concentration alone or with the lowest rate of analcite.

Application of analcite in the concentration of $500 \mathrm{mg}$ per pot completely compensated for the negative effect of $\mathrm{Cd}$ on the dry weight accumulation by shoots and roots of corn and hemp test-plants. The concentration of $250 \mathrm{mg}$ per pot was somewhat less effective.

\section{Discussion}

Sufficient literature supports the phytotoxic effect of $\mathrm{Cd}$ in excessive concentrations (Simova-Stoilova et al., 2004; Irfan et al., 2015; Li et al., 2018; Loi et al., 2018). The present investigation showed that growth characteristics, especially those of shoots of corn, and hemp, significantly decreased after the application of $\mathrm{CdSO}_{4}$, even at the lowest concentration tested $(0.1 \%)$. The values for these growth parameters decreased with an increasing accumulation of $\mathrm{Cd}$ in foliar tissues of the test-plants. This tendency confirmed the suggestion that the rate of absorbance and accumulation of this heavy metal by target plants, for the most part, determine the size of its harmful effect on the latter. In our study, the accumulation of $\mathrm{Cd}$ in the foliar tissues of test-plants was accompanied by the increase in the content of other toxic metals such as $\mathrm{Mn}, \mathrm{Fe}$, and $\mathrm{Cu}$, which could further exacerbate symptoms of Cd toxicity.

Many authors report the negative impact of $\mathrm{Cd}$ on the growth characteristics of various crop species (Irfan et al., 2015; Li et al., 2018). In our study, the application of analcite in a concentration of $500 \mathrm{mg}$ per pot completely compensated for the negative effect of $\mathrm{Cd}$ on the growth characteristics of the test-plants. A similar tendency was demonstrated by Silva et al. (2017) with $\mathrm{K}_{2} \mathrm{SiO}_{3}$ as a source of $\mathrm{Si}$ and corn (Zea mays 'São José') as a test-plant in the model laboratory experiments. 
Table 3. The interactive effect of $\mathrm{CdSO}_{4}$ and analcite on the content of photosynthetic pigments in the corn leaves, $\mathrm{mg} / \mathrm{g}$ of fresh weight $(\mathrm{x} \pm \mathrm{SE}, \mathrm{n}=6)$.

\begin{tabular}{llllll}
\hline \multirow{2}{*}{ Treatment } & & \multicolumn{2}{c}{ Chlorophyll } & & \\
\cline { 3 - 5 } & & $a$ & $b$ & & \\
Control & & $12.4 \pm 0.61$ & $6.1 \pm 0.10$ & 2.03 & $2.4 \pm 0.19$ \\
$\mathrm{CdSO}_{4}$ & $0.1 \%$ & $6.4 \pm 0.32$ & $5.0 \pm 0.19$ & 1.28 & $1.2 \pm 0.15$ \\
& $0.5 \%$ & $6.7 \pm 0.29$ & $5.4 \pm 0.13$ & 1.24 & $2.8 \pm 0.21$ \\
$0.1 \% \mathrm{CdSO}_{4}+$ analcite & $0.1 \mathrm{~g}$ & $5.7 \pm 0.31$ & $5.6 \pm 0.12$ & 1.01 & $1.3 \pm 0.11$ \\
& $0.25 \mathrm{~g}$ & $6.1 \pm 0.37$ & $5.8 \pm 0.12$ & 1.05 & $1.5 \pm 0.15$ \\
& $0.5 \mathrm{~g}$ & $7.1 \pm 0.29$ & $6.1 \pm 0.11$ & 1.16 & $3.1 \pm 0.11$ \\
$0.5 \% \mathrm{CdSO}_{4}+$ analcite & $0.1 \mathrm{~g}$ & $5.1 \pm 0.29$ & $5.6 \pm 0.10$ & 0.91 & $2.1 \pm 0.12$ \\
& $0.25 \mathrm{~g}$ & $6.2 \pm 0.22$ & $6.1 \pm 0.22$ & 1.01 & $2.4 \pm 0.18$ \\
& $0.5 \mathrm{~g}$ & $5.9 \pm 0.32$ & $5.7 \pm 0.16$ & 1.04 & $2.3 \pm 0.16$ \\
\hline
\end{tabular}

Table 4. The interactive effect of $\mathrm{CdSO}_{4}$ and analcite on the content of photosynthetic pigments in the hemp leaves, $\mathrm{mg} / \mathrm{g}$ of fresh weight $(x \pm S E, n=6)$.

\begin{tabular}{llllll}
\hline \multirow{2}{*}{ Treatment } & & \multicolumn{2}{c}{ Chlorophyll } & & \\
\cline { 3 - 5 } & & $a$ & $b$ & & \\
Control & & $10.8 \pm 0.23$ & $4.8 \pm 0.10$ & 2.25 & $2.2 \pm 0.07$ \\
$\mathrm{CdSO}_{4}$ & $0.1 \%$ & $4.1 \pm 0.14$ & $2.0 \pm 0.08$ & 2.05 & $1.2 \pm 0.15$ \\
& $0.5 \%$ & $3.7 \pm 0.15$ & $1.8 \pm 0.08$ & 2.05 & $2.4 \pm 0.11$ \\
$0.1 \% \mathrm{CdSO}_{4}+$ analcite & $0.1 \mathrm{~g}$ & $3.5 \pm 0.19$ & $2.0 \pm 0.09$ & 1.75 & $2.4 \pm 0.09$ \\
& $0.25 \mathrm{~g}$ & $3.9 \pm 0.11$ & $2.8 \pm 0.11$ & 1.39 & $2.8 \pm 0.12$ \\
& $0.5 \mathrm{~g}$ & $4.8 \pm 0.16$ & $2.9 \pm 0.10$ & 1.66 & $2.9 \pm 0.08$ \\
$0.5 \% \mathrm{CdSO}_{4}+$ analcite & $0.1 \mathrm{~g}$ & $3.3 \pm 0.14$ & $2.2 \pm 0.09$ & 1.50 & $2.6 \pm 0.11$ \\
& $0.25 \mathrm{~g}$ & $3.8 \pm 0.18$ & $2.4 \pm 0.09$ & 1.58 & $2.9 \pm 0.08$ \\
& $0.5 \mathrm{~g}$ & $4.5 \pm 0.17$ & $2.4 \pm 0.11$ & 1.87 & $2.8 \pm 0.09$ \\
\hline
\end{tabular}

Siliceous minerals have been documented to mitigate the phytotoxicity of heavy metals, including cadmium (Liang et al., 2007; Silva et al., 2017; Bhat et al., 2019; Dong et al., 2019). However, the physiological mechanisms underlying this phenomenon are still not clear. In general, there are thought to be two types of mechanisms, viz. external (ex planta) and internal (in planta) involved in Si-regulated plant resistance to toxic metals (Liang et al., 2007; Bhat et al., 2019). External mechanisms include reducing toxic metal availability via immobilization due to a rise in $\mathrm{pH}$ or forming Si-mediated insoluble complexes with organic or mineral fraction of the soil (Liang et al., 2007; Bhat et al., 2019; Dong et al., 2019). The role of $\mathrm{Si}$ in minimizing uptake and root-toshoot transport of Cd ions was confirmed in a number of studies on various crops (Shi et al., 2005; Silva et al., 2017; Dong et al., 2019; Bhat et al., 2019). Shi et al. (2005) suggested that the deposition of $\mathrm{Si}$ near the endodermis might offer a possible mechanism by which siliceous minerals physically block the apoplast bypass flow across the roots and restrain the apoplastic transport of $\mathrm{Cd}$ to shoots.

In our study, Si concentration in the tissues of the Si-treated plants was significantly higher (see Tables 1 \& 2) compared to plants grown without analcite. Si accumulation in both corn and hemp plants was in good correlation with their growth characteristics and reduction of 
Table 5. The interactive effect of $\mathrm{CdSO}_{4}$ and analcite on the dry weight of corn and hemp plants in $\mathrm{mg}$ $(x \pm S E, n=24)$.

\begin{tabular}{lllll}
\hline \multirow{2}{*}{ Treatment } & & \multicolumn{2}{l}{ Corn } & Hemp (whole plant) \\
\cline { 3 - 4 } & & Shoots & Roots & $13.04 \pm 0.66$ \\
\hline Control & & $83.03 \pm 1.64$ & $36.39 \pm 1.13$ & $10.23 \pm 0.56$ \\
$\mathrm{CdSO}_{4}$ & $0.1 \%$ & $67.28 \pm 1.53$ & $39.87 \pm 2.61$ & $11.71 \pm 052$ \\
& $0.5 \%$ & $65.32 \pm 1.86$ & $31.31 \pm 1.72$ & $10.12 \pm 1.01$ \\
$0.1 \% \mathrm{CdSO}_{4}+$ analcite & $0.1 \mathrm{~g}$ & $63.12 \pm 2.14$ & $39.95 \pm 1.35$ & $9.66 \pm 0.74$ \\
& $0.25 \mathrm{~g}$ & $75.02 \pm 2.53$ & $31.19 \pm 1.06$ & $10.72 \pm 0.66$ \\
& $0.5 \mathrm{~g}$ & $68.49 \pm 1.89$ & $33.40 \pm 1.13$ & $11.04 \pm 0.77$ \\
$0.5 \% \mathrm{CdSO}_{4}+$ analcite & $0.1 \mathrm{~g}$ & $65.91 \pm 2.23$ & $29.83 \pm 1.01$ & $12.31 \pm 1.05$ \\
& $0.25 \mathrm{~g}$ & $74.21 \pm 1.83$ & $35.17 \pm 1.57$ & $12.82 \pm 1.17$ \\
\hline
\end{tabular}

Cd concentrations in foliar tissues, confirming the described above physical defense mechanism suggested by Shi et al. (2005). Plant species vary in their ability to accumulate Si. It is thought that higher accumulators obtain greater defense after silicon application (Bhat et al., 2019). Our results demonstrated that hemp accumulated significantly higher $\mathrm{Si}$ amounts than corn. However, the mitigating effect of analcite on $\mathrm{Cd}$ accumulation was more noticeable in corn, especially at a higher $(0.5 \%)$ rate of the $\mathrm{Cd}$ salt application. Thus, the results of our study clearly indicated a speciesspecific difference of $\mathrm{Cd}$ translocation and other factors influencing the detoxification mechanism of Si on Cd toxicity, also reported by other authors (Dong et al., 2019).

Some authors also suggested an external interaction between $\mathrm{Si}$ and $\mathrm{Cd}$, resulting in the formation of soil mineral complexes absorbing and immobilizing Cd (Liang et al., 2007; Bhat et al., 2019; Dong et al., 2019). Dong et al. (2019) demonstrated that Si application reduced exchangeable/oxidizable/reducible $\mathrm{Cd}$ in soil and increased residual $\mathrm{Cd}$, which is considered not bioavailable to plants. Liang et al. (2007) reported that $\mathrm{Si}$ application decreased water-extractable fractions of $\mathrm{Cd}$, but increased $\mathrm{Fe}-\mathrm{Mn}$ oxide-bound fractions. Therefore more $\mathrm{Cd}$ was found in the form of specific adsorbed or Fe-Mn oxide-bound fractions in Si-amended soil. Our results clearly indicated that application of analcite also reduced $\mathrm{Fe}$ and $\mathrm{Mn}$ concentrations in the corn and hemp tissues, suggesting possible immobilization of these metals in soil, which confirmed the hypothesis of Liang et al. (2007).

In our study Cd-stressed plants had inhibited photosynthetic function (viz. lower chlorophyll $a$ and $b$ content in leaves). Similar results were obtained by other authors demonstrating reduction of net photosynthetic rate, the photosynthetic quantum yield of PSII, and chlorophyll $a$ and b content in plants (Irfan et al., 2015). Among possible physiological mechanisms of the described phenomenon, Cd-induced ABA signals decreasing stomatal conductance, which negatively affects the photosynthetic carbon fixation cycle, were suggested (Irfan et al., 2015). Stimulation of carotenoids content in foliar tissues of Cd-stressed corn and hemp plants indicated intensification of stressful conditions. The application of analcite at a rate of $500 \mathrm{mg}$ per pot compensated for the negative effect of $\mathrm{CdSO}_{4}$ and alleviated the $\mathrm{Cd}$-induced reduction of the chlorophylls $a$ and $b$. Carotenoids and chlorophyll $b$ play a major role in the protection of photosynthetic systems against photooxidative processes. They are efficient antioxidants scavenging singlet molecular oxygen and peroxyl radicals (McElroy \& Kopsell, 2009). Therefore, the content of chlorophyll $b$ and carotenoids is sensitive to the influence of abiotic and biotic stress factors, and the ratio of these pigments to the content of chlorophyll $a$ is a marker of plant stress. The inhibiting effect of $\mathrm{Cd}$ on plants is related to the damage of protective 
antioxidant systems (Simova-Stoilova et al., 2004). The increased content of chlorophyll $b$ induced by the application of analcite indicates activation of antioxidant defense mechanisms, which contributed to the better adaptive capacity of the Cd-stressed test-plants.

The revealed tendency for the distribution of photosynthetic pigments in the corn foliar tissues is consistent with the studied characteristics of seedlings' growth rates. In particular, with increasing chlorophyll content, the characteristics of seedlings' growth increased correspondingly.

There are numerous publications reporting that phytotoxic concentrations of $\mathrm{Cd}$ cause an imbalance of nutrients in target plants (Irfan et al., 2015; Jibril et al., 2017). The changes are species-specific and depend on the environmental factors, viz. type of soil, macroand micronutrients availability and so on (Irfan et al., 2015; Jibril et al., 2017). In our study, the application of $0.1 \%$ of $\mathrm{CdSO}_{4}$ to corn and hemp increased some micronutrients' content in foliar tissues. Higher $(0.5 \%)$ concentration of the Cd salts inhibited up-take almost of all the studied nutrients.

Combined application of $\mathrm{Cd}$ salt with analcite significantly modified absorption and accumulation of macro- and micronutrients by corn and hemp plants. The character of the analcite effect depended on its concentration, the $\mathrm{Cd}$ salt concentration, and the species of a test-plant. When applied in combination with $\mathrm{CdSO}_{4}$ in low concentrations (100-250 mg per pot), analcite could stimulate absorption and accumulation of $\mathrm{Cd}$ as well as some other macro- and micronutrients in foliar tissues of the test-plants. Particularly, it stimulated uptake of $\mathrm{Al}, \mathrm{P}, \mathrm{S}$, and $\mathrm{Si}$ in corn and hemp plants. At the same time, concentrations of toxic metals such as $\mathrm{Mn}$ and $\mathrm{Cu}$ were inhibited. Application of analcite at the highest concentration significantly reduced the amount of $\mathrm{Cd}$ accumulated in the leaves of both test plants (Tables $1 \& 2$ ).

The combined use of $\mathrm{Cd}$ salts and the analcite demonstrated a somewhat different tendency in corn and hemp. The increase in $\mathrm{Ca}$ concentration in foliar tissues of corn plants treated with the mixture of $\mathrm{Cd}$ salt and analcite indicates a close relationship between the redox state of the cellular membranes and the regulation of the cation channel through which proteins pass due to the presence of specific thiol groups in the channel (Kohli et al., 2017).

Thus, the results obtained confirmed the positive role of silicon in stimulating the resistance of corn and hemp plants at the earliest stages of their development. In our study, Si-enhanced tolerance to $\mathrm{Cd}$ can be attributed not only to $\mathrm{Cd}$ immobilization in soil due to absorption on analcite particles but also to Si-mediated physiological changes which condition uptake of macro- and micronutrients by test-plants.

\section{Conclusions}

The data obtained in the present study confirmed the inhibiting effect of $\mathrm{Cd}$ on the growth, content of chlorophylls in leaves, absorption, and allocation to leaves of macro- and micronutrients in higher plants. The degree of inhibition positively correlated with the rate of $\mathrm{Cd}$ application and differed significantly between the studied crop species of corn and hemp. Particularly, hemp demonstrated not only a much higher capacity to accumulate this heavy metal in the foliar tissue but also was more tolerant to its phytotoxic effect. Application of analcite at a rate of $500 \mathrm{mg}$ per pot substantially reduced phytoavailability of $\mathrm{Cd}$, which was reflected in the much lower accumulation of this heavy metal in the foliar tissues of the test-plants. As a result, the characteristics of the growth of corn and hemp plants exposed to Cd were restored, and the content of chlorophylls and macro- and micronutrients in the leaves of Cd-stressed plants improved significantly. When applied at lower concentrations (100 mg and $250 \mathrm{mg}$ ), analcite could stimulate uptake of $\mathrm{Cd}$ (when the latter was applied at low concentration), as well as the allocation of this heavy metal to the foliar tissues. The size of the analcite protective effect was higher on corn as compared to hemp in terms of reducing $\mathrm{Cd}$ uptake and increased plant growth.

\section{References}

Adiloglu, S. (2018). Heavy metal removal with phytoremediation. In N. Shiomi (Ed.), Advances in bioremediation and phytoremediation (pp. 115126). Intech, Tekirdağ, Turkey. https://doi. org/10.5772/intechopen.70330 
Augustsson, A. L., Uddh-Soderberg, T. E., Hogmalm, K. J., \& Filipsson, M. E. (2015). Metal uptake by homegrown vegetables - the relative importance in human health risk assessments at contaminated sites. Environmental Research, 138, 181-190. https://doi.org/10.1016/j. envres.2015.01.020

Bhat, J. A., Shivaraj, S. M., Singh, P., Navadagi, D. B., Tripathi, D. K., Dash, P. K., Solanke, A. U., Sonah, H., \& Deshmukh, R. (2019). Role of silicon in mitigation of heavy metal stresses in crop plants. Plants, 8(3), Article 71. https://doi. org/10.3390/plants8030071

Chorna, V. I., Voroshylova, N. V., \& Syrovatko, V. A. (2018). Cadmium distribution in soils of Dnipropetrovsk oblast and its accumulation in crop production. Ukrainian Journal of Ecology, 8(1), 910-917. (In Ukrainian)

Dong, Q., Fang, J., Huang, F., \& Cai, K. (2019). Silicon amendment reduces soil $\mathrm{Cd}$ availability and $\mathrm{Cd}$ uptake of two Pennisetum species. International Journal of Environmental Research and Public Health, 16(9), Article 1624. https://doi.org/10.3390/ ijerph16091624

Dubey, S., Shri, M., Misra, P., Lakhwani, D., Bag, S. K., Asif, M. H., Trivedi, P. K., Tripathi, R. D., \& Chakrabarty, D. (2014). Heavy metals induce oxidative stress and genome-wide modulation in transcriptome of rice root. Functional \& Integrative Genomics, 14, 401-417. https://doi.org/10.1007/ s10142-014-0361-8

Feszterová, M., Porubcová, L., \& Tirpáková, A. (2021). The monitoring of selected heavy metals content and bioavailability in the soilplant system and its impact on sustainability in agribusiness food chains. Sustainability, 13(13), Article 7021. https://doi.org/10.3390/ su13137021

Hussain, I., Akhtar, S., Ashraf, M. A., Rasheed, R., Siddiqi, E. H., Ibrahim, M. (2013). Response of maize seedlings to cadmium application after different time intervals. International Scholarly Research Notices, 2013, Article 169610. https://doi. org/10.1155/2013/169610

Irfan, M., Hasan, S. A., Hayat, S., \& Ahmad, A. (2015). Photosynthetic variation and yield attributes of two mustard varieties against cadmium phytotoxicity. Cogent Food \& Agriculture, 1(1). https://doi.org/10.1080/23311932.2015.11 06186

Jibril, S. A., Hassan, S. A., Ishak, C. F., \& Wahab, P. E. (2017). Cadmium toxicity affects phytochemicals and nutrient elements composition of lettuce (Lactuca sativa L.). Advances in Agriculture, 2017, Article 1236830. https://doi. org/10.1155/2017/1236830
Khan, M. A., Khan, S., Khan, A., \& Alam, M. (2017). Soil contamination with cadmium, consequences and remediation using organic amendments. Science of the Total Environment, 601-602, 1591-1605. https://doi.org/10.1016/j. scitotenv.2017.06.030

Kohli, S. K., Handa, N., Gautam, V., Bali, S., Sharma, A., Khanna, K., Arora, S., Thukral, A. K., Ohri, P., Karpets, Y. V., Kolupaev, Y. E., \& Bhardwaj, R. (2017). ROS signaling in plants under heavy metal stress. In M. Khan, N. Khan (Eds.), Reactive oxygen species and antioxidant systems in plants: role and regulation under abiotic stress (pp. 185-214). Springer. https://doi. org/10.1007/978-981-10-5254-5_8

Krychkovska, L. V. Bielinska, A. P., Ananieva, V. V., Dybonosov, V. L., \& Ovsiannicova, T. O. (2017). Food products safety: antialimentary factors, xenobiotics, food additives: a textbook. NTU KhPI. (In Ukrainian)

Li, S., Wang, M., Zhao, Z., Li, X., Han,. Y., \& Chen, S. (2018). Alleviation of cadmium phytotoxicity to wheat is associated with $\mathrm{Cd}$ re-distribution in soil aggregates as affected by amendments. RSC Advances, 31, Article 8, 17426-17434. https://doi. org/10.1039/C8RA03066A

Liang, Y., Sun, W., Zhu, Y., \& Christie, P. (2007). Mechanisms of silicon-mediated alleviation of abiotic stresses in higher plants: a review. Environmental Pollution, 147(2), 422-428. https:// doi.org/10.1016/j.envpol.2006.06.008

Linger, P., Ostwald, A., \& Haensler, J. (2005). Cannabis sativa L. growing on heavy metal contaminated soil: growth, cadmium uptake and photosynthesis. Biologia Plantarum, 49, 567-576. https://doi.org/10.1007/s10535-0050051-4

Loi, N. N., Sanzharova, N. I., Shchagina, N. I., \& Mironova, M. P. (2018). The effect of cadmium toxicity on the development of lettuce plants on contaminated sod-podzolic soil. Russian Agricultural Sciences, 44, 49-52. https://doi. org/10.3103/S1068367418010111

McElroy, J. S., \& Kopsell, D. A. (2009). Physiological role of carotenoids and other antioxidants in plants and application to turfgrass stress management. New Zealand Journal of Crop and Horticultural Science, 37(4), 327-333. https://doi. org/10.1080/01140671.2009.9687587

Rinkis, G. Y., \& Nollendorff, V. F. (1982). Balanced supply of plants with macro- and microelements. Zinatne. (In Russian)

Shi, X. H., Zhang, C. C., Wang, H., \& Zhang, F. S. (2005). Effect of Si on the distribution of $\mathrm{Cd}$ in rice seedlings. Plant and Soil, 272, 53-60. https:// doi.org/10.1007/s11104-004-3920-2 
Silva, A. J., Nascimento, C. W. A., \& GouveiaNeto, A. S. (2017). Assessment of cadmium phytotoxicity alleviation by silicon using chlorophyll a fluorescence. Photosynthetica, 55(4), 648-654. https://doi.org/10.1007/s11099-0160680-1

Simova-Stoilova, L., Stoyanova, Z., \& DernirevskaKepova, K. (2004). Effect of Cd toxicity on the levels of some antioxidant enzymes and compounds in the leaves of young barley plants. Comptes Rendus de l'Academie Bulgare des Sciences, 57, 45-50.

Wellburn, A. R. (1994). The spectral determination of chlorophylls $a$ and $b$, as well as total carotenoids, using various solvents with spectrophotometers of different resolution. Journal of Plant Physiology, 144(3), 307-313. https://doi.org/10.1016/s01761617(11)81192-2
Zaimenko, N. V., Didyk, N. P., Pavliuchenko, N. A., Ivanytska, B. O., Kharytonova, I. P., \& Rositska, N. V. (2018). Natural silicates mixed with organic fertilizers enhance corn adaptation to salt stress and improve physical characteristics of sandy soil. Journal of Crop Improvement, 32(2), 188-207. https://doi.org/10.1080/15427528.201 7.1405856

Zaimenko, N. V., Ivanytska, B. O., Didyk, N. P., \& Kharytonova, I. P. (2021). Use of siliceous minerals as natural nitrification inhibitors. Biology and Life Sciences Forum, 4(1), Article 38. https://doi.org/10.3390/IECPS2020-08744

Zhigailo, E. (2011). The control for perennial grasses heavy metals contamination in the Odessa province irrigation land. Ukrainian Hydrometeorological Journal, 8, 155-161. (In Ukrainian)

\section{Вплив анальциму на фітодоступність та фітотоксичність кадмію}

Наталія Заіменко 1, *, Богдана Іваницька ', Наталія Дідик 1, Олена Малащук ', Джамал Рахметов 1, Віталій Гришко ${ }^{2}$, Анастасія Полякова ${ }^{3}$, Мирон Пизик ${ }^{4}$, Ян Сласкі $^{5}$

${ }^{1}$ Національний ботанічний сад ім. М.М. Гришка НАН України, вул. Тимірязєвська 1, Київ, 01014, Україна

2 Криворізьський ботанічний сад, НАН України, вул. Маршака 50, Кривий Ріг, 50089, Україна

3 Глухівський національний педагогічний університет ім. Олександра Довженко, вул. КиєвоМосковська, 24, Глухів, Сумська обл., 41400, Україна

${ }^{4}$ Об'єднаний інститут сучасних технологій, вул. 10225, буд. 147, Едмонтон, Альберта, Т5N 3С1, Канада

${ }^{5}$ Відділення Біо-промислових служб, ІнноТек Альберта, Хайвей 16А, буд. 75, Вегревіль, Альберта, Т9С 1Т4, Канада

Проаналізовано вплив Cd та природного кремнієвого мінералу анальциму на фітотоксичність $\mathrm{Cd}$ і швидкість накопичення в рослинних тканинах. Дослідні рослини кукурудзи та коноплі вирощували за контрольованих умов освітленості, температури та вологості ґрунту упродовж 21 доби у таких варіантах: (1) без будь-яких добавок (контроль); (2) з внесенням 0,1% і 0,5\% (за масою) $\mathrm{CdSO}_{4} ;$ (3) з внесенням солі $\mathrm{Cd}\left(\mathrm{CdSO}_{4}\right)+$ анальциму 0,1 г, 0,25 г і 0,5 г. Продуктивність дослідних рослин оцінювали за ростовими характеристиками (висоти пагона та довжини кореня), вмістом у листках фотосинтетичних пігментів, макро- та мікроелементів. Вплив $\mathrm{Cd}$ на рослини кукурудзи та коноплі пригнічував їх ріст, біосинтез хлорофілу в листках, призводив до зміни балансу макрота мікроелементів, що мало наслідком накопичення Cd у тканинах пагонів обох досліджуваних культур. Встановлено, що застосування анальциму частково компенсує негативний вплив солей Cd на ріст сільськогосподарських рослин, вміст хлорофілу і баланс поживних речовин, а також значно зменшує накопичення $\mathrm{Cd}$ у пагонах.

Ключові слова: анальцим, Cd, фітодоступність, фітотоксичність, накопичення макроелементів, накопичення мікроелементів, фотосинтетичні пігменти, кукурудза, коноплі 